\title{
BIOTECHNOLOGY
}

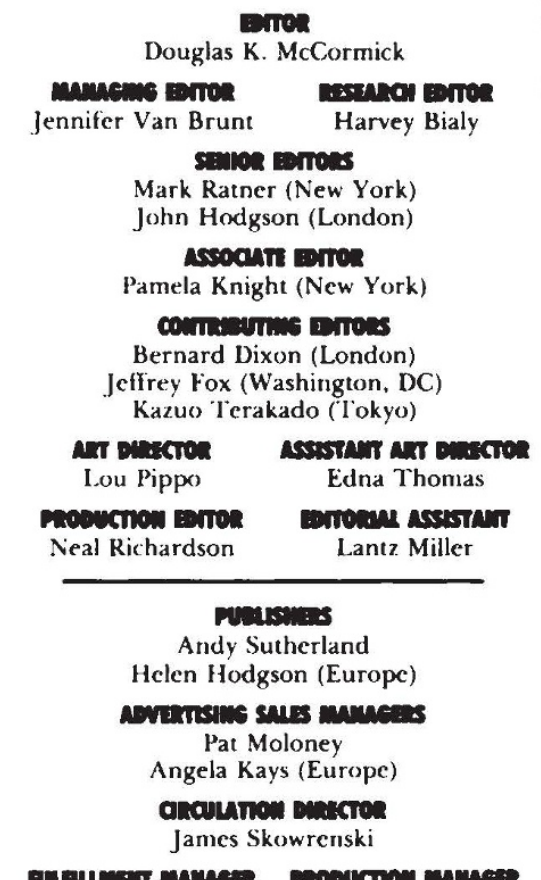

Funumat mane:

Bruce Shriver, Jr. Estelle Selzer

$$
\begin{gathered}
\text { 65 Bleecker St., New York, NY. } 10012 \\
\text { Tel: (212) 477-9600. Fax: (212)505-1364. } \\
4 \text { Little Fissex St., London WC.2R 3LF } \\
\text { Tel. (071) 872-0103. Fax: (071) 240-2408 } \\
\text { remo } \\
\text { (o Newton, Shinjuku Horai Bldg. } \\
\text { 20 Nishishinjuku-1 chome } \\
\text { Shinjuku-ku. Tokyo } 160, \\
\text { Tel: } 03(344) 4862 \text {. Fax: } 03(348) 6744
\end{gathered}
$$

sca:mak arreon eas.

George Poste, SmithKline Beecham

Ken-ichi Arai, DNAX Research Institute

Teruhiko Beppu, University of Tokyo

Ronald E. Cape, Cetus Corporation

Jean-Pierre Changeux, Institut Pasteur

Mary-Dell Chilton, CIBA-Geigy

Nam-Hai Chua, Rockefeller University

Rita R. Colwell, Maryland Biotechnology Institute

Arnold Demain, Massachusetts Institute of Technolugy

J. Lawrence Fox, Abbott Laboratories

David Goeddel, (jenentech

Leroy Hood, California Institute of

Technology

Morio Ikehara, Protein Engineering Research Institute

Ernest Jaworski, Monsanto Company

Irving Johnson

David Mount, University of Arizona

Victor Nussenzweig, New York University

Medical Center

Carl-Gustaf Rosen, Abitec AB

Kendall Smith, Dartmouth Medical School

Yukio Sugino, Takeda Chemicals

Marc Van Montagu, Plant Genetic Systems

Indra K. Vasil, University of Florida

Lemuel B. Wingard, University of Pittsburgh

Wataru Yamaya, Seikagaku Kogyo

\section{THE FIRST WORD}

\section{INTERCONTINENTAL DIVIDE}

$\mathrm{W}$ e first noticed it in Tokyo in 1988, during a panel discussion of national biotechnology policies at the Japanese Bioindustry Development Council (BIDEC) meeting. And we saw it again last month outside Copenhagen during a roundtable luncheon at the Fifth European Congress on Biotechnology: Biotechnologists from different continents make starkly different assumptions about the way new science transforms into new technology and new technology transmutes into new products.

The conversations in Japan and Denmark-Europeans predominated in both groups-fell quickly into rehearsals of governmental, quasi-governmental, and super-governmental development schemes. The talk was full of bureaucratese, directive numbers, and cumbersome planning councils with fanciful acronyms-with a few vague references to unpublicized programs undertaken inhouse by giant corporations.

Missing was the noisy ferment of up-start start-ups, the hyperbolic technical boasting, the rattling of gilded tin cups on the corners of Wall Street familiar from the North American biotechnology scene.

In "European Biopharmaceutical Culture," senior editor John Hodgson posits three possible roots of the differences between North American and European biotechnology: a persistence of an American frontier spirit, a U.S. advantage in proprietary technology, and "the relative paucity of venture funding in Europe." These may, in fact, be three aspects of the same thing.

It is tempting to dismiss the reference to frontier spirit as the Old World romanticizing the New, but perhaps it is fundamental. In Democracy in America, Alexis De Tocqueville remarked on the citizens' collective genius for tackling problems and opportunities directly-by collecting a committee of like-minded fellows and setting to work.

Venture capitalism is but this national character in its financial aspect: a group of like-minded men and women who see an opportunity and set their money to work on it. And the possible U.S. edge in proprietary technology proceeds from the leverage the venture mechanism offers those who can develop and establish claim to a new idea.

Granted, the American venture capital markets have their own peculiar pathologies. They have spawned a particularly noisome species of pseudoscientific hype. And they are blinkered by a next-quarter myopia that has made longterm business planning in the U.S. rarer than the American bison (which is, we should note, reestablishing itself on controlled ranges, public and commercial).

But the U.S. venture markets are also a vital, responsive, and altogether ingenious mechanism for spreading risk and allocating resources to new ideasa device without exact parallel anywhere in the world. And it is most peculiar to listen to serious people reviewing the sources of energy to drive biotechnology development without any mention of this dynamo.

At the same time, the North American jingoist must recognize that U.S. biotechnology is so visible in part because it so obstreperous: The nestful of hatchlings shouting for worms is much more evident than the owl perching in the bole. One should not confuse noise with power.

In Europe, biotechnology is a more civilized, more institutionalized pursuit. It is nurtured by bankers, megacorporate executives, and bureaucrats. The system is averse to risk and vulnerable to political pressure-conventional electoral politics, pressure-group harassment, or the internal politics of a massive company (which can rival a small nation in population and complexity). In any case, the system excels at long-range planning, dotting the $i$ 's and crossing the $t$ 's. But it does a poor job of surfing on the tide of opportunity. 